\title{
Thymus zygioides Grisebach var. zygioides'in Morfolojik, Anatomik ve Ekolojik Özellikleri
}

\author{
Şamil Koyuncu, İsmet Uysal*, Onur Esen, Bahar Kökçü, Furkan Şahin, Duygu \\ Peksüsler, Bahar Aktura \\ Çanakkale Onsekiz Mart Üniversitesi, Fen Edebiyat Fakültesi, Biyoloji ABD
}

\section{Özet}

Lamiaceae familyasına ait olan Thymus L. cinsi ülkemizde 46 tür ve tür altı taksonla temsil edilmekte olup, çok yıllık, aromatik ve tıbbi değeri olan otsu bir bitkidir. Önemli bir etnobotanik değere sahip olan Thymus zygioides Griseb. var. zygioides kozmopolit bir taksondur. Çalışmamıza ait bitki örnekleri 2014 yılının Mayıs ayında Lapseki'den (Çanakkale) toplanmıştır. Araştırmamızda bu türün morfolojik, anatomik ve ekolojik özelliklerinin belirlenmesi amaçlanmıştır. Morfolojik özelliklerini belirlemek için bitkinin biometrik ölçümleri lup altında gerçekleştirilmiştir. Anatomik çalışmaları için \%70'lik alkole alınan canlı bitki örneklerinin; kök, gövde ve yaprağından parafin metodu kullanılarak enine kesitler alınmıştır. Anatomik özellikleri, yapılmış olan benzer araştırmalarla karşılaştırılmıştır. Bitkinin yayılış alanları belirlenirken; toprak analizleri sonucu değerlendirilmiştir. Bu araştırma sonuçlarının endemik olan varyete ile karşılaştırılması önemlidir. Taksonun biometrik ölçümleri flora kayıtlarından önemli farklılık göstermemiştir.

Anahtar kelimeler: morfoloji, anatomi, ekoloji, Lamiaceae , Thymus

\section{The Morphological, Anatomical and Ecological Characteristics of Thymus zygioides Grisebach var. Zygioides}

\begin{abstract}
The genus Thymus, belonging to Lamiaceae family and represented by 46 species and taxa is a herbaceous, perennial, medical and aromatic plant. Thymus zygioides Griseb. var. zygioides is a cosmopolitan taxon with an important ethnobotanical value. Plant samples were collected from Lapseki Çanakkale, on May 2014. In this study, it was aimed to determine the morphological, anatomical and ecological characteristics of this plant. Biometric measurements of the plant were carried out under the lup to determine morphological characteristics. Cross sections of root, stem and leaves of live plant samples were taken with $\% 70$ alcohol for anatomical studies using paraffin method. Anatomical features were compared with the findings of similar studies. Soil analyses results were considered in the determination of plant's expansion area. It is important to compare these results with the endemic variety. The biometric measurements of the taxa did not differ significantly from the flora records.
\end{abstract}

Keywords: morphology, anatomy, ecology, Lamiaceae, Thymus 


\section{Giriş}

Lamiaceae familyası dünyada 245 cins ve 7.886 adet tür içeren çok geniş bir familyadır (TPL, 2013). Bir çok aromatik ve tıbbi bitkileri bünyesinde barındıran Lamiaceae familyası tıp, kimya, gıda, zirai mücadele, kozmetik ve çeşitli sanayi alanlarında kullanışı nedeniyle etnobotanik açısından önemli bir familyadır (Alan ve Koca, 2007). Bu familyaya ait Thymus L. cinsi ülkemizde 46 tür ve 46 tür altı taksonla temsil edilmekte ve bu taksonlardan 18 'i endemik türler arasında yer almaktadır (Bizimbitkiler.org, 2016).

Kekiğin organları taze veya kurutulmuş halde baharat olarak kullanılırken; aynı zamanda çayı, yağı ve suyuyla geniş bir kullanım alanına sahiptir. Bir çok sanayi alanında kullanım imkanı bulunan Thymus, eski çağlardan beri en fazla tıbbi yararları bilinerek kullanılmış ve gün geçtikçe bu alanda sağlam bir yer edinmiştir (Altundağ ve Aslım, 2005).

Bitkilerin sınıflandırmasına katkı sağlayan anatomik çalışmalar özellikle Thymus gibi drog olarak kullanılan cinslerin tanınmasında da önemli bir rol oynamaktadır (Alan ve Koca, 2007). Bu araştırmada önemli etnobotanik değeri olan ve tıbbi amaçla da drog olarak değerlendirilen Thymus zygioides var. zygioides'in morfolojik, anatomik ve ekolojik özelliklerinin ortaya konması amaçlanmıştır.

\section{Materyal ve Metot}

Araştırma materyali olarak kullanılan "Bodur Kekiği” olarak adlandırılan Thymus zygioides var. zygioides 2014 yılının Mayıs ayında "Lapseki (A1/A), (Çanakkale, Türkiye) ve Çevresinin Etnobotaniği” adlı Yüksek Lisans Tezi araştırmaları kapsamında Lapseki'nin Karamusalar Köyü ile Çamyurt Köyü arasındaki yol kenarından toplanmıştır (Bizimbitkiler.org, 2016; Kökçü, 2015).

Toplanan materyalin bir kısmı bitki tayini, morfolojik çalışmalar için ayrılırken diğer bir kısmı ise anatomik çalışmalar için fikse edilmiştir. Ayrıca bitkinin yayılış gösterdiği habitatında genel görünüşü, habitat özellikleri belirlenmiş, yaprak, çiçek ve köklerinin fotoğrafları çekilmiştir. Bitkinin teşhisi "Flora of Turkey and the East Aegean Island" ve "Flora of Europea" gibi çeşitli floristik eserlerden yararlanılarak yapılmıştır (Davis 1982; Heywood ve ark. 1964-1980).

Teşhis edilen örneklerin bir kısmı, ayrıntılı morfolojik özelliklerinin belirlenmesi için biometrik ölçümleri yapılırken; bir kısmı ise herbaryum örneği haline getirilerek Çanakkale Botanik Bahçesi Herbaryumu'nda korumaya alınmıştır. Anatomik çalışmalar için ise \%70'lik alkol içerisinde fikse edilmiş bitki numunelerinin kök, gövde ve yaprak gibi kısımlarından ve organlarından parafin metodu kullanılarak enine kesitler alınmıştır. Daha sonra sürekli preparat haline getirilerek mikroskop altında fotoğrafları çekilmiştir. Anatomik çalışmalar iki bitki materyali ve 15 preparat üzerinden değerlendirme yapılmıştır.

Materyallerin toplandığı lokalitelerden alınan toprak örnekleri, $20 \mathrm{~cm}$ derinlikten ve bitkinin yayılış gösterdiği 4 populasyondan alınmış ve polietilen torbalarla laboratuvara getirilmiştir. Hava kurusu yapılan topraklar, 2 mm'lik elekten geçirilerek analizlere hazır hale getirilmiştir. Daha sonra toprağın; maksimum su tutma kapasitesi, $\mathrm{pH}$, total tuz, kireç, bünye, azot, fosfor, potasyum ve organik madde analizleri yapılmıştır (Öztürk ve ark., 1983). 


\section{Bulgular}

Thymus zygioides, birisi endemik olmak üzere 2 adet varyetesi bulunmaktadır. Thymus zygioides var. lycaonicus (Celak) Ronniger endemik iken, çalışma konumuz olan Thymus zygioides var. zygioides kozmopolit bir taksondur. Bitkinin yayılış gösterdiği habitatından genel morfolojik görüntüsü aşağıda verilmiştir (Şekil 1).

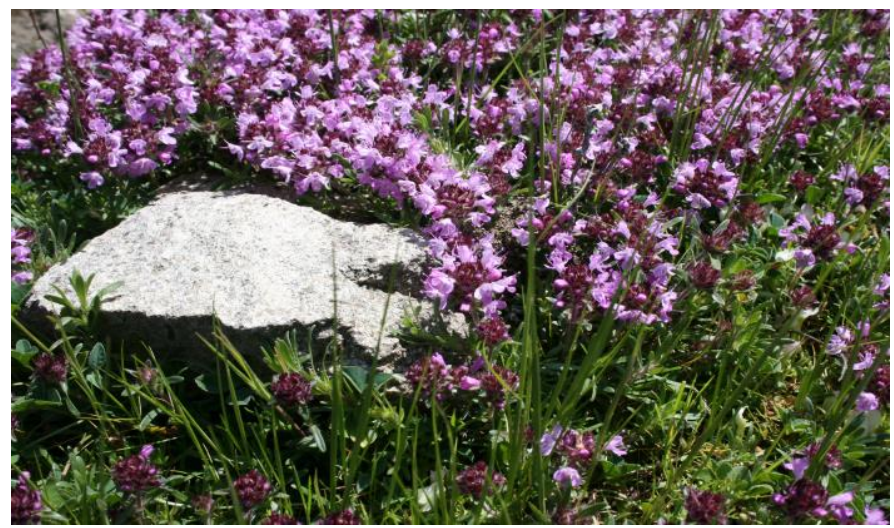

Şekil 1. Thymus zygioides var. zygioides'in genel görünüşü

\subsection{Morfolojik Özellikleri}

Çiçeklenen gövdeler 2.12-4.1 cm, uç kısımda aksillar yaprak demetlerini taşıyan uzun ve sarılıcı odunsu dallar bulunduran çok yıllık bir bitkidir. Gövdeler, arkaya doğru bükülmüş tüyler taşımaktadır. Yapraklar karnoz olup 5.41 -11,66 x 0.80 - $1.75 \mathrm{~mm}$ ince, darca spatulat, obtus, damarlar belirgin ve kenarlarındaki kısa tüyler hariç tüysüzdür. Kenar sili $2 \mathrm{~mm}$ kadardır. Yapraklarda seyrek bulunan yağ benekleri sarıdan turuncuya doğru değişmektedir. Brakteler 3,93-9,43 x 1.30-3.14 mm, ovat-ligulattan eliptiğe doğru değişir. Taban soluk ve \pm çıkıntılı damarlar taşır. Brakteoler 1,17- 2.0 mm, lanseolattan eliptiğe değişir (Şekil 2). Kaliks 0,609-1,51 x 0,228-0,458 mm, hafif mor renkli, üç köşeli ve 2 dudaklıdır. Kaliks tüpü dudaklardan daha kısa, üstteki dudağın dişleri 0,47- 0,687 mm ve genellikle sillidir. Korolla 2.31-6.30 mm kadar, pembe ve 2 dudaklidır. Stamenler 4 tane olup, 0,302-1,29 mm korolladan uzundur. Pistil 1, 0,479- 1,53 mm ovaryum üst durumlu, 4 loplu, 2 lokuluslu ve karpellidir (Şekil 3, Tablo 1). Ovüller 4 tane olup, anatroptur. Stilus ginobaziktir. Meyve 4 nutletten oluşmuştur. Çiçeklenme zamanı Nisan ile Haziran ayları arasındadır. Deniz seviyesinden 1600 m'ye kadar yüksekliklerde bulunur (Davis, 1982).

Tablo 1. Thymus zygioides var. zygioides'in biyometrik ölçümleri

\begin{tabular}{|c|c|c|c|c|c|c|}
\hline Bitki Kısmı & $\begin{array}{c}\text { Boy } \\
\text { Min.(mm) }\end{array}$ & $\begin{array}{c}\text { Boy } \\
\text { Maks.(mm) }\end{array}$ & $\begin{array}{c}\text { En } \\
\text { Min.(mm) }\end{array}$ & $\begin{array}{c}\text { En } \\
\text { Maks.(mm) }\end{array}$ & $\begin{array}{c}\text { Boy Ort. } \pm \text { Standart } \\
\text { Sapma (mm) }\end{array}$ & $\begin{array}{c}\text { En } \\
\text { Ort. } \pm \text { Standart } \\
\text { Sapma (mm) }\end{array}$ \\
\hline Yaprak & 5,41 & 11,66 & 0,8 & 1,75 & $8,89 \pm 1,50$ & $1,22 \pm 0,24$ \\
\hline Brakte & 3,93 & 9,43 & 1,3 & 3,14 & $6,99 \pm 1,78$ & $2,18 \pm 0,56$ \\
\hline Brakteol & 1,17 & 2 & - & - & $1,63 \pm 0,25$ & - \\
\hline Çiçek K1sm1 & & & - & & & $3,89 \pm 1,34$ \\
\hline Korolla & 2,31 & 6,3 & - & - & $0,98 \pm 0,17$ & $3,34 \pm 0,07$ \\
\hline Kaliks & 0,609 & 1,51 & 0,228 & 0,458 & $0,55 \pm 0,07$ & - \\
\hline Kaliks Dişi & 0,47 & 0,687 & - & - & $0,57 \pm 0,21$ & - \\
\hline Stamen & 0,302 & 1,29 & - & - & $0,96 \pm 0,24$ & - \\
\hline Pistil & 0,479 & 1,53 & - & - & & \\
\hline
\end{tabular}


Uysal ve ark. 2017

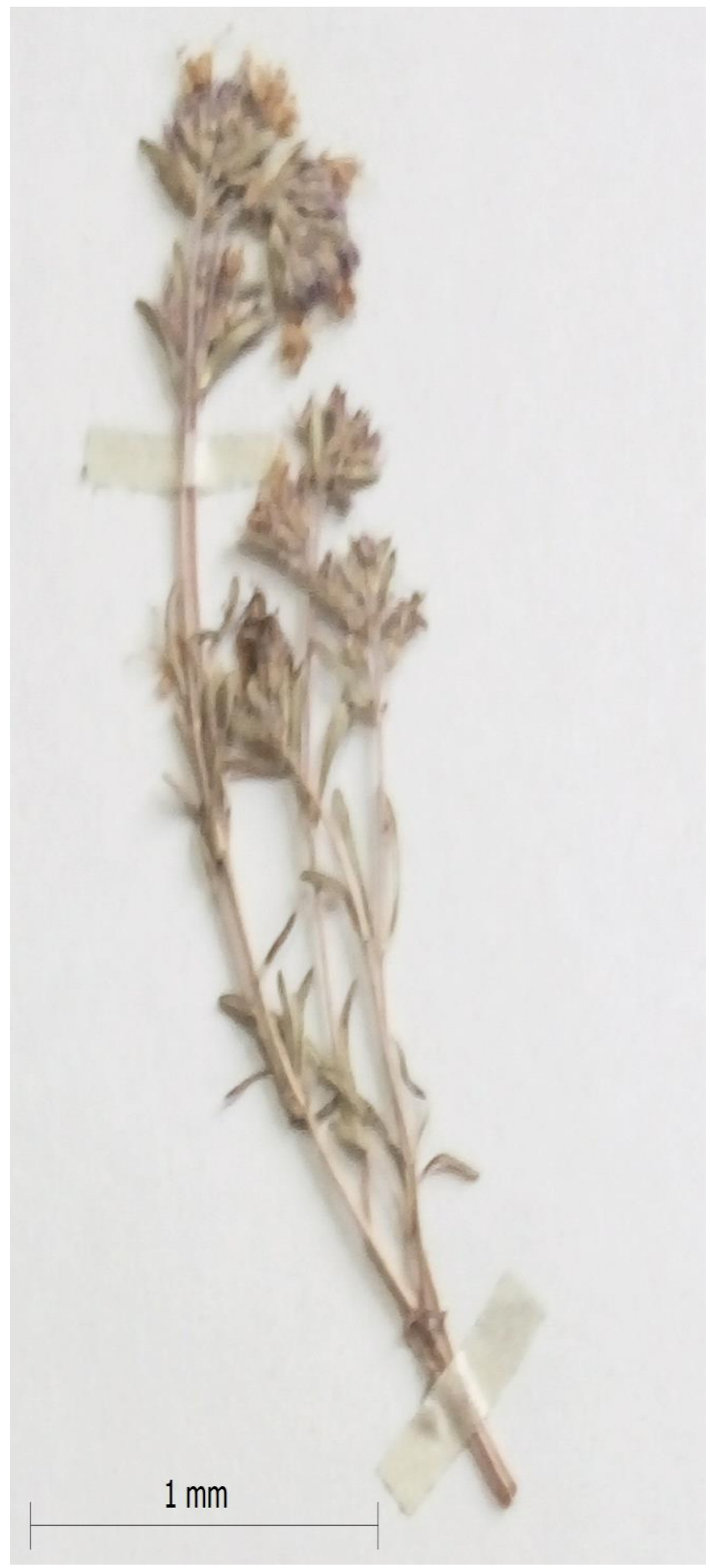




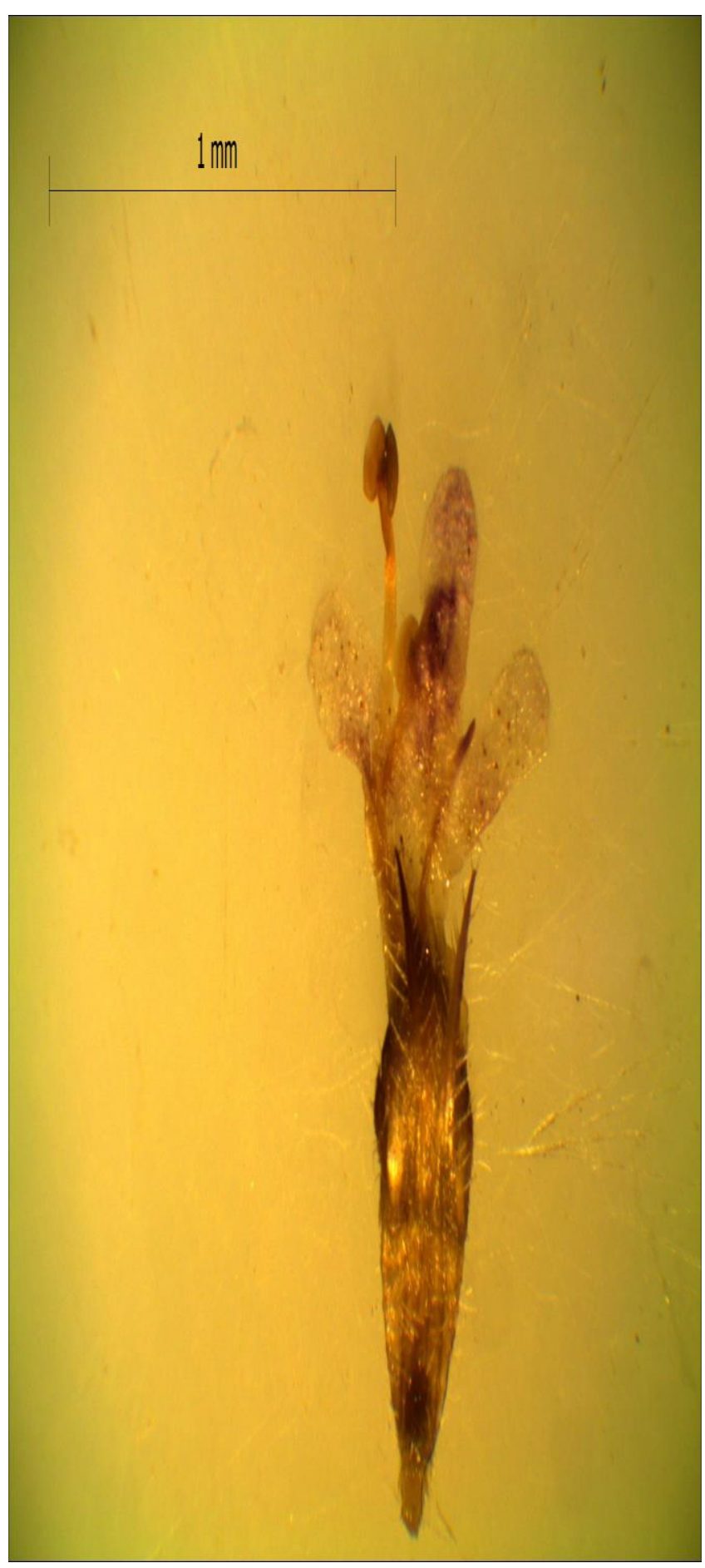

Şekil 2. Thymus zygioides var. zygioides'in çiçekli dalı ve çiçeğinden genel görünüş. 
Uysal ve ark. 2017

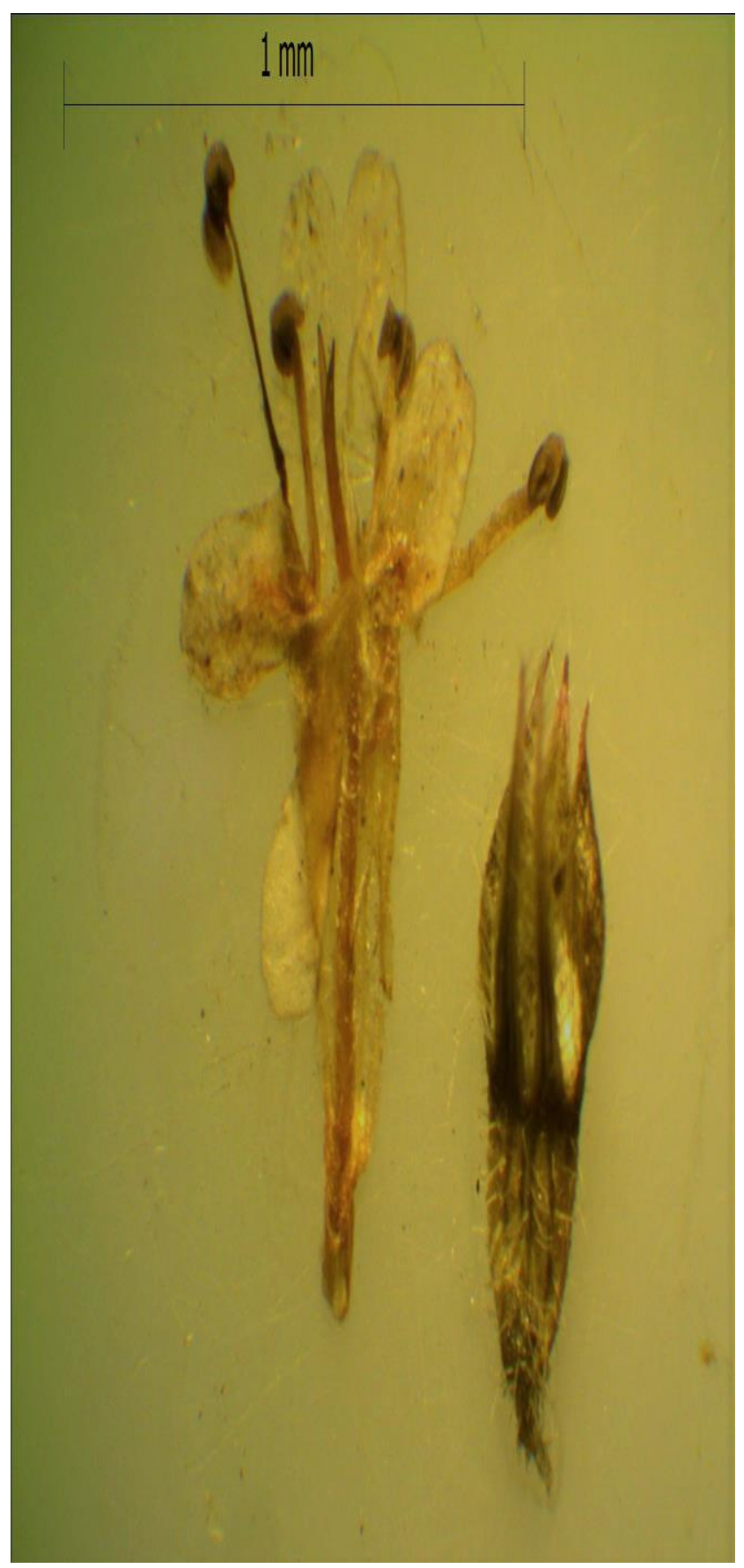




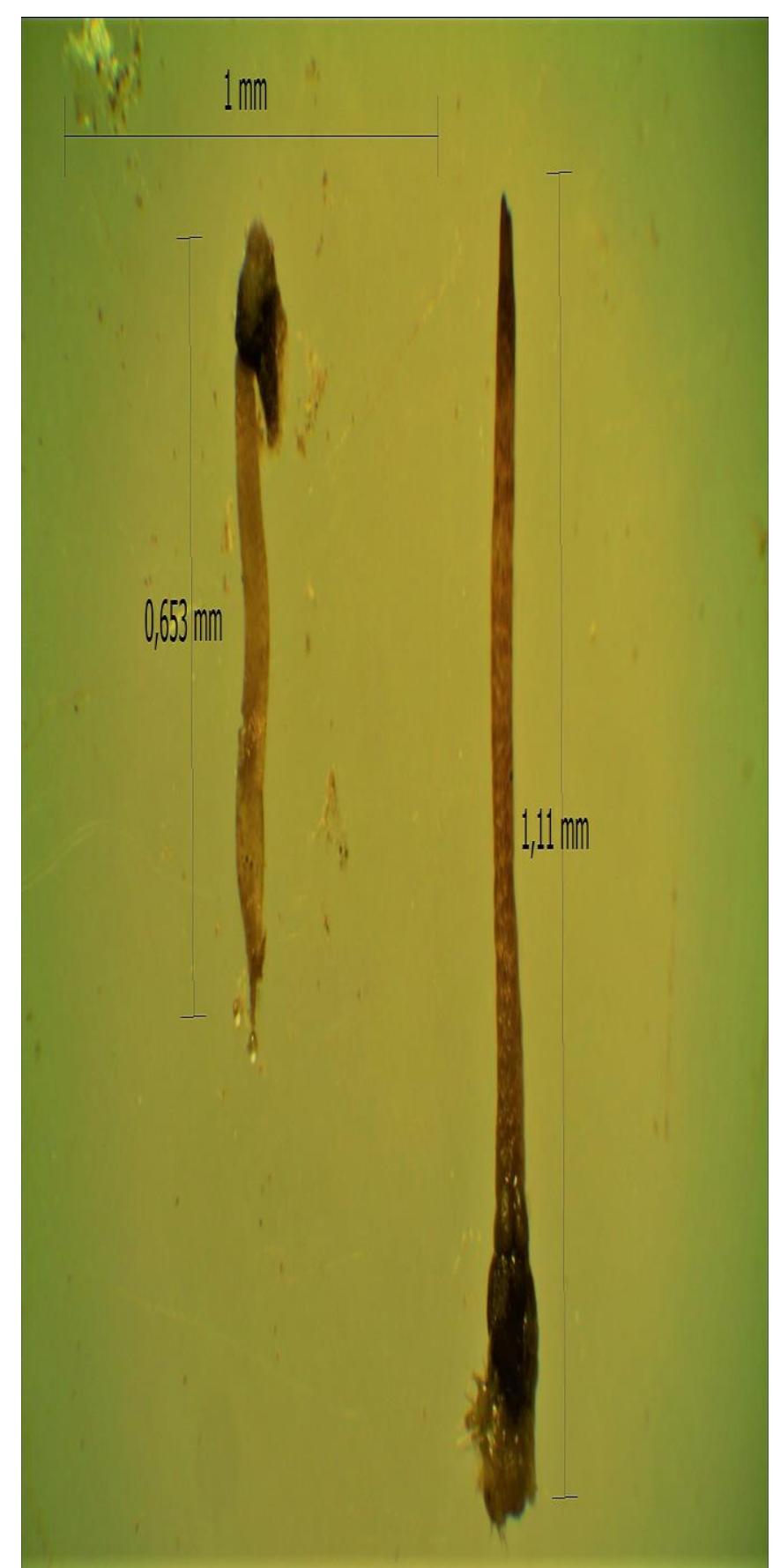

Şekil 3. Thymus zygioides var. zygioides'in korolla, kaliks, anter ve filament'inden genel görümüş.

\subsection{Anatomik Özellikleri}

Bitkinin kök, gövde ve yaprağından alınan enine kesitlerle anatomik yapısı ortaya konmaya çalışılmıştır.

\subsubsection{Kök Anatomisi}

En dişta çok sıralı ekzodermis, altında 3-4 sıra çeşitli şekilli hücrelerden oluşmuş korteks gelmektedir. Daha sonrasında ise uzun ve yassı hücrelerden oluşmuş endodermis yer almaktadır. Endodermisin altında periskl çok iyi ayırt edilememektedir. Daha sonra iletim demetinde floem ve ksilem arasında yer alan kambiyum iyi seçilememektedir. İletim 
demetinde floem ksileme göre daha az bir alan kaplamaktadır. Bitkinin çok yıllık olmasına bağlı olarak ksilem geniş bir alanda yer almakta olup, öz ksilem elemanlarıyla doldurulmuştur (Şekil 4).

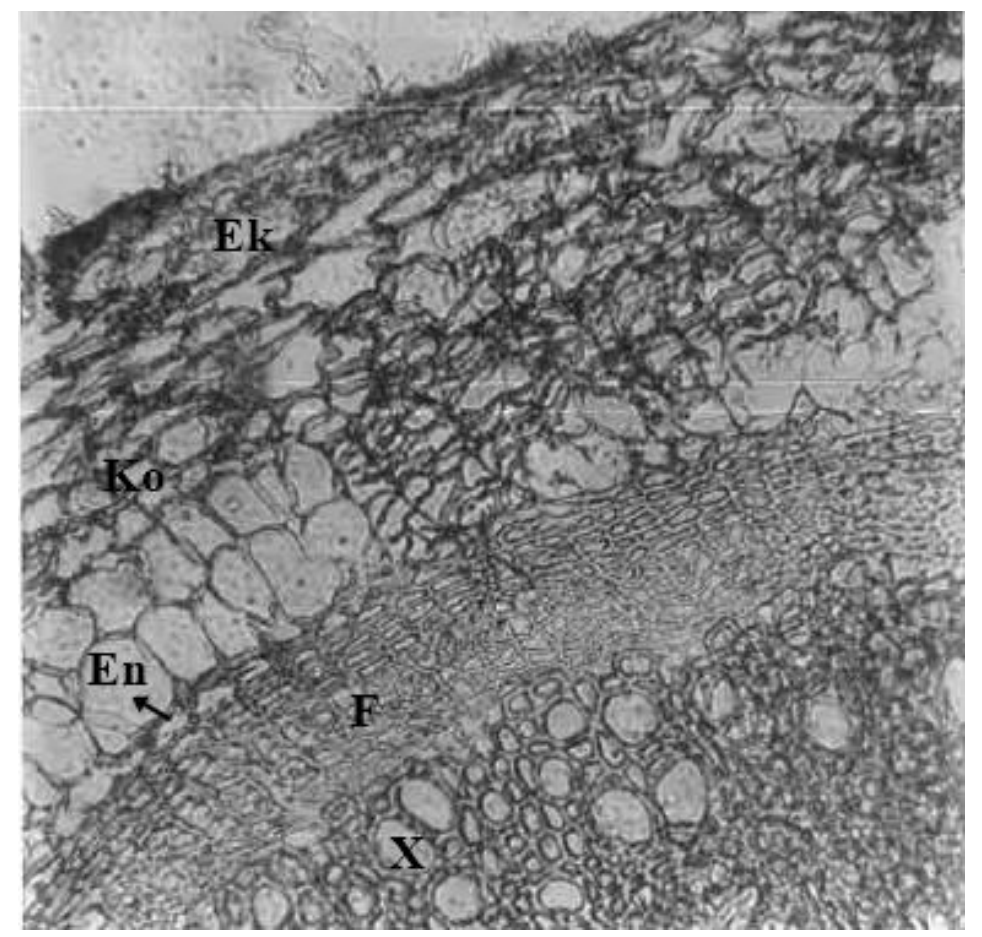

Şekil 4. Thymus zygioides var. zygioides'in kök enine kesidi

Ek:Ekzodermis, Ko:Korteks, En:Endodermis, F:Floem, X:Ksilem

\subsubsection{Gövde Anatomisi}

Tipik 4 köşe olan gövde de, köşeler kalın çeperli kollenkimatik hücrelerden oluşmaktadır (Şekil 4). En dıșta kalın bir kutikula, altında irili ufaklı hücrelerden oluşmuş epidermis altında tek sıralı hipodermis yer almaktadır. Epidermisten bol miktarda örtü ve salgı tüyü çıkmaktadır. Daha sonra iri parenkimatik hücrelerden oluşan geniş bir klorenkimatik korteks doku gelmektedir. Korteksi oluşturan hücreler iletim dokuya doğru giderek küçülmektedir. En içte endodermis olarak tanımlayabileceğimiz bir hücre sırası gözlemlenmiştir. Bu durum Uysal ve ark. (1991) ile Alan ve Koca (2007) tarafından yapılan çalışmalarda da rapor edilmiştir. Daha sonra dar bir alanı kaplayan floem ve geniş bir alanı dolduran ksilemden oluşan iletim demeti gelmektedir. Ksilemden sonra ise parenkimatik öz bulunmaktadır. Floem ile ksilem arasında yer yer kambiyum görülmektedir (Şekil 5). 
Şekil 5. Thymus zygioides var. zygioides'in gövde enine kesidi

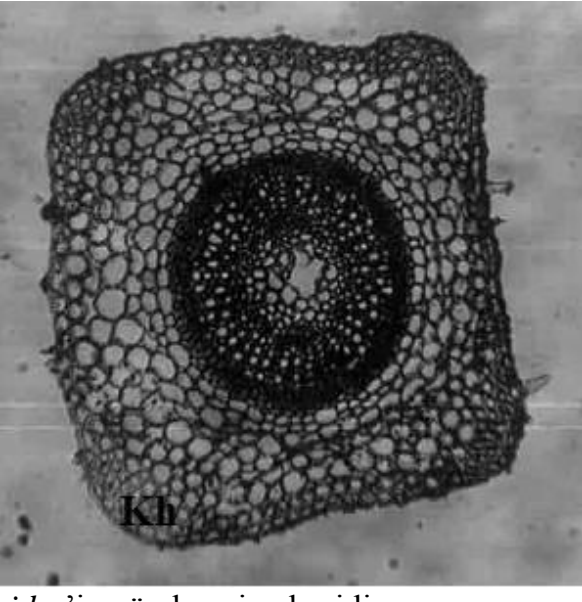

Kh: Kollenkimatik hücreler

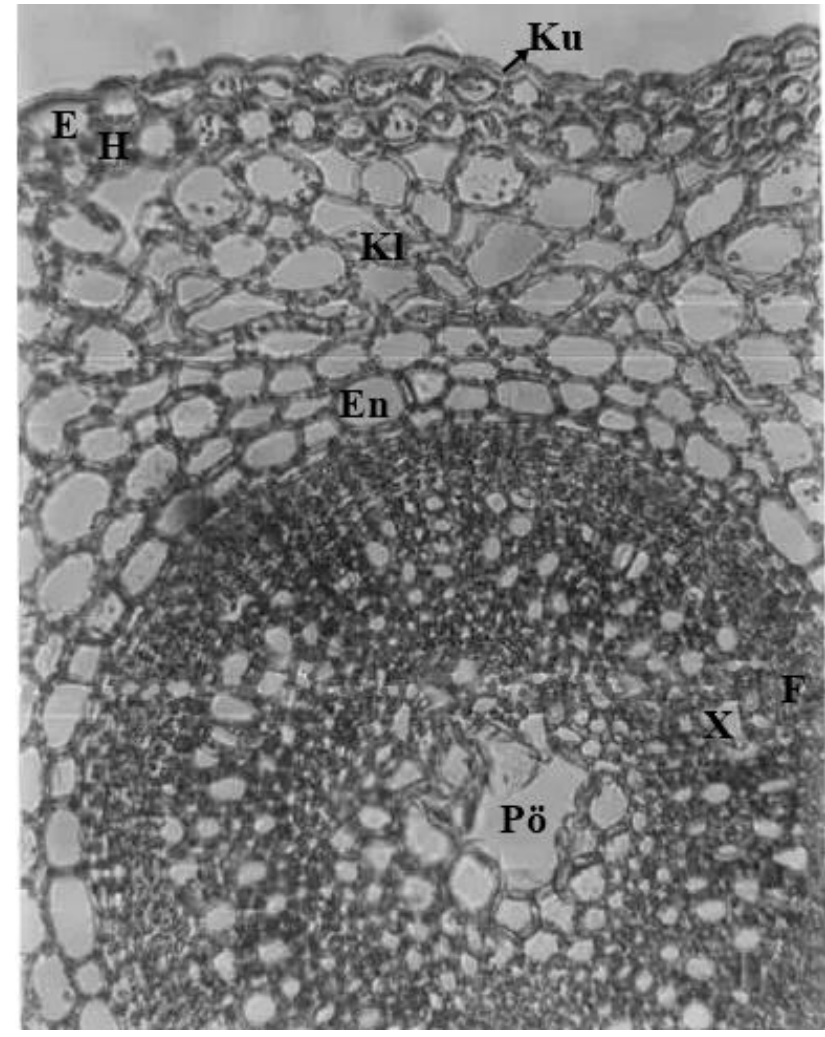

Şekil 6. Thymus zygioides var. zygioides'in gövde enine kesidi

Ku:Kutikula, E:Epidermis, H:Hipodermis, Kl:Klorenkimatik doku, En:Endodermis, F:Floem, X:Ksilem, Pö:Parenkimatik öz

\subsubsection{Yaprak Anatomisi}

En dışta kalın bir kutikula ve altında tek sıralı epidermis yer almaktadır (Şekil 7). Epidermisten çok bol miktarda örtü ve salgı tüyü çıkmaktadır. Ayrıca epidermiste amaryllis tipi stoma bulunmaktadır (Şekil 8). Stomalar epidermis ile aynı seviyede yer aldığı için bitki mezofitik özellik göstermektedir. Mezofil palizat ve sünger parekimasından meydana gelmiştir. Palizat parenkiması 1-2 sıralı olup, daha sonra gelen sünger parenkiması ise dağınık dizilişli 3-4 sıralı hücrelerden oluşmaktadır. Mezofilin hem alt hem üst yüzeyinde palizat parenkiması yer alması sebebiyle yaprak ekvifasiyaldir. Yaprağın hem alt hem üst yüzeyinde stomaların bulunması nedeniyle yaprak amfistomatiktir. Merkezde yer alan iletim demeti en 
büyüğüdür. Demetin etrafi parenkimatik bir kın ile çevirilidir. Dışta ksilem içte floem yer almakta olup floemin dişında büyük bir sklerankimatik doku bulunmaktadır. Mezofilde bol miktarda rafid kristallerine rastlanmıştır.

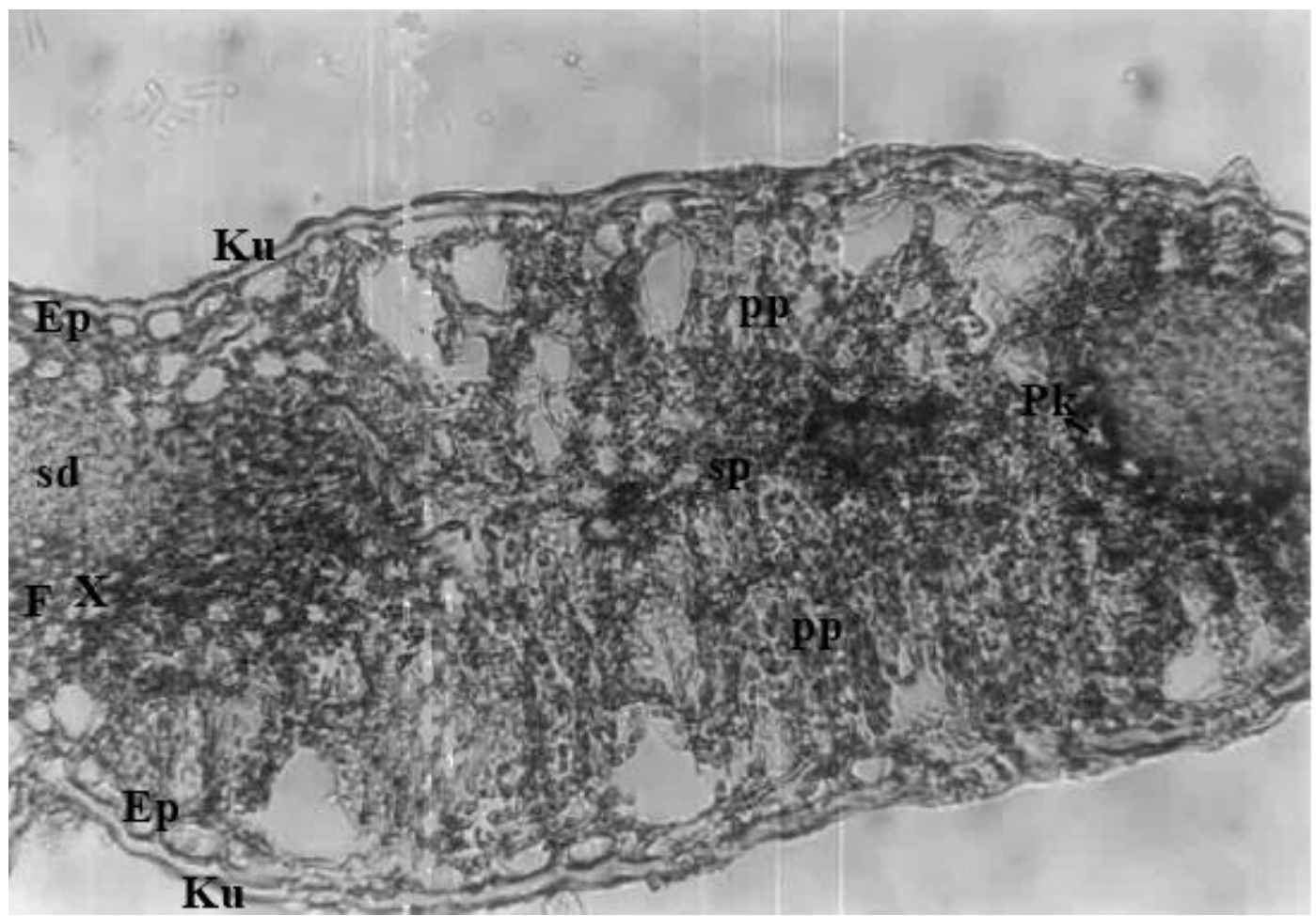

Şekil 7. Thymus zygioides var. zygioides'in yaprak enine kesidi

Ku:Kutikula, E:Epidermis, pp:Palizat parankiması, sn:Sünger parankiması, Pk:Parenkimatik kın, X:Ksilem, F:Floem, sd:Sklerankimatik doku

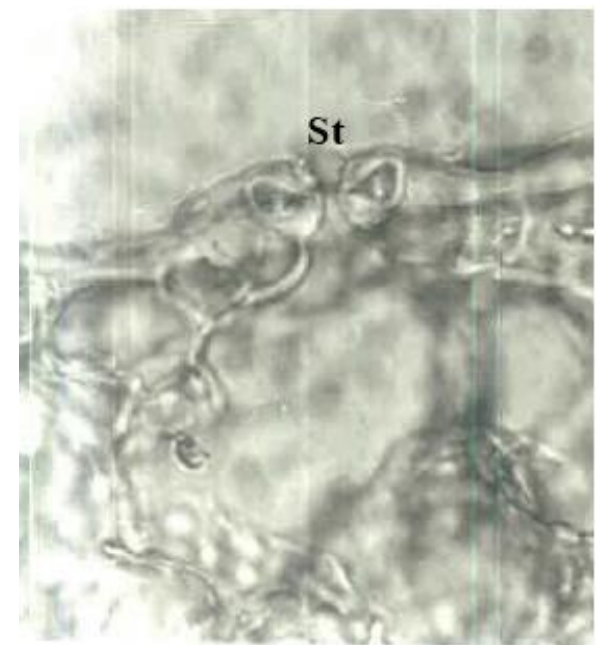

Şekil 8. Thymus zygioides var. zygioides'in yaprak enine kesidinde amaryllis tip stoma

St:Stoma

\subsection{Ekolojik Özellikleri}

\subsubsection{Yayılış ve yayılış alanlarının özellikleri}

Davis (1982)'e göre Çanakkale Eceabat ve Erenköy, İstanbul Kızılcaali, Denizli Çankurtaran ile Çukurköy arasında Honaz Dağı'nda 900 m'de ve Tuzlacı' da yayılış göstermektedir. Bitki, 
kumsal alanlarda, Pinus brutia Ten. orman altlarında, kayalık yerlerde ve maki açıklıklarında bulunmaktadir.

Araştırmamızda Thymus zygioides var. zygioides'in Çanakkale'de Lapseki'nin Karamusalar Köyü ile Çamyurt Köyü arasındaki yol kenarlarından toplanmıştır. Bu yol üzerinde geniş bir alanda yayılış göstermektedir.

\subsubsection{Toprağın Fiziksel ve Kimyasal Özellikleri}

Thymus zygioides var. zygioides'in toprağının fiziksel analizlerinde $\mathrm{pH}$ 's1 5.82 yani orta asit karakterde, tuzsuz, kireç miktarı \%0.042 yani kireççe fakir olarak bulunmuştur. Toprak bünye sınıfı kumlu-tınlıdır. Maksimum su tutma kapasitesi \%37.1 olarak bulunmuştur.

Bitkinin toprağının kimyasal analiz sonuçlarını incelendiğinde ise, azotun \%0.056 yani azotça orta, fosforun \%0.051 yani fosforca zengin, potasyumun $\% 0.13$ yani potasyumca yetersiz ve organik maddenin \%5.172 olarak oldukça zengin olduğu görülmüştür.

\section{Sonuçlar ve Tartışma}

Bodur kekiği olarak adlandırılan Thymus zygioides türünün iki adet varyetesi bulunmaktadır. $\mathrm{Bu}$ varyetelerden incelediğimiz Thymus zygioides var. zygioides'in endemik olan Thymus zygioides Griseb. var. lycaonicus'dan; üst kaliks dişlerinin uzunlukları 1.56-2.80 mm, gövdesinin üst kısmındaki tüylerin 1.12-0.48 mm uzunlukları ve bu tüylerin geriye doğru dönük olması ile yaprakların üzerindeki yağ damlacıklarının sarı renkten turuncu renge dönük olmasıyla ayırt edilmektedir (Davis, 1982).

Thymus zygioides var. zygioides'in morfolojik özellikleri (Davis, 1982) ile taksonun deskripsiyonu birbiri ile uyumlu olurken dijital ölçüm aletiyle elde edilen ölçümlerin, brakteoller hariç, verilen değerlerden daha küçük olduğu gözlemlenmiştir. Ayrıca kaliks eni, stamen boyu ve pistil boyu ölçümleri de tarafımızca ilk kez yapılmıştır ve biyometrik ölçümlerin istatistik sonuçları da standart sapma olarak verilmiştir.

Bitkinin kökünden alınan enine kesitlerin anatomik gözlemleri sonucunda, genç köklerinde yaşlandıkça hücrelerinde suberinleşme meydana gelerek, epidermisin ölmesiyle dişa doğru koruyucu tabaka olan ekzodermisin oluştuğu gözlemlenmiştir (Yentür ve Öz, 2013). Aynı türün diğer endemik varyetesi olan Thymus zygioides var. lycaonicus'un kök anatomisinin incelenmesinde ekzodermise rastlanılmamış olup, kutikula tabakasından sonra korteksin yer aldığı belirtilmiştir. Bu farklılığın araştırılan Thymus zygioides var. lycaonicus'un bitkisinin daha genç olduğu ve bu nedenle ekzodermisin daha ortaya çıkmadığını göstermektedir (Kesercioğlu ve ark., 1990). Bitkinin çok yıllık bir bitki olması ve bunun sonucunda sekonder kalınlaşma göstermesi nedeniyle ekzodermis altında yer alan korteks daralmıştır.

Bitkinin gövdesi, tipik dört köşeli gövde olup, köşelerinde kollenkimatik hücrelerin varlığ1 Lamiaceae familyasının ayırt edici özelliklerindendir (Metcalfe ve Chalk, 1950). En dişta yer alan kutikula tabakasının kalın olması su kaybını önlemede etkilidir. Epidermis tek tabaklı olmayıp hipodermis tabakası da yer almaktadır. Kesitlerde çok belli olmamakla birlikte epidermis tabakasından bol miktarda örtü ve salgı tüyü çıkmaktadır. Korteksteki klorenkimatik hücreler, fotosentez yaparak bu önemli olaya gövdeyi de dahil etmektedir. Endodermis kökten farklı olarak iri hücrelerden oluşmaktadır. Bu durum Uysal ve ark. (1991) ile Alan ve Koca (2007) tarafından yapılan çalışmalarda da rapor edilmiştir. Floem ve ksilem arasında sekonder kalınlaşmayı sağlayan kambiyum yer yer ayırt edilmiştir. Gövdenin öz 
bölgesi belirgin parenkimatik hücrelerden oluşmuştur. Thymus zygioides var. lycaonicus'un gövde anatomisinden hipodermisin varlığı dışında bir farklılık görülmemiştir (Kesercioğlu ve ark., 1990).

Bitkinin yaprak anatomisinde üst ve alt kısımda en dışta kutikula tabakası görülmektedir. Kutikulanın yaprağın iki tarafında bulunması bitkinin suyu olabildiğince yapraklarında tutmaya çalıştığını göstermektedir. Birçok örtü ve salgı tüyüyle birlikte amaryllis tip stomanın da epidermis tabakasından farklılaştığı görülmektedir. Hem alt hem üst epidermiste yer alan stomalar amfistomatik tip stomadır. Mezofitik özellik gösteren bitkimizin stomaları epidermisle aynı seviyede yer almaktadır ki bu da bitkimizin 1lıman kuşaklarda yaşamayı tercih ettiğini göstermektedir. Mezofil tabakasında palizat ve sünger tabakası birbirinden ayırt edilebilmekte ve aralarında rafid kristalleri yer almaktadır. Palizat ve sünger parankimasının durumuna göre bifasiyal yapraktır. İletim demeti elemanlarından ksilem üstte belirgin halde floem ise altta yer almaktadır. Parenkimatik kınla çevrili olan iletim demetleri sklerankimatik doku sayesinde bitkiye desteklik sağlanmıştır. Thymus zygioides var. lycaonicus'un yaprak anatomisinde belirtilen diastik stomanın varlığı görülememiştir (Kesercioğlu ve ark., 1990).

Bitkinin yetiştiği toprağın, fiziksel ve kimyasal analizleri ilk kez tarafımızdan incelenmiştir. Toprağının analizlerinde pH'sı orta asit karakterde, tuzsuz, kireççe fakir olarak kaydedilmiştir. Toprağının bünye sınıfı kumlu-tınlıdır. Toprağın maksimum su tutma kapasitesinin düşük olması, bitkinin topraktan aldığ 1 suyu tutmak için kalın ve belirgin bir kutikula tabakasına sahip olmasını açıklamaktadır. Ayrıca topraktaki su ve mineralleri almak isteyen bitki, kök hücrelerinde ve emici tüylerindeki osmotik basıncı arttırarak, topraktaki su ve mineralleri enerji harcanmadan almaktadır. Stomaların açılıp kapanmasında değişen osmotik basınç bu mekanizmada etkili olurken, bitkinin sahip olduğu bol miktardaki stomalar bu olaya katkı sağlamaktadır. Bitkinin yetiştiği toprağının kimyasal analiz sonuçları incelendiğinde ise, azotça orta, fosforca zengin, potasyumca yetersiz ve organik madde miktarı açısından oldukça zengin olduğu belirlenmiştir.

Özellikle tıbbi açıdan değerli olan Thymus çeşitli araştırmalar sonucunda; doku ve damar büzücü, iştah açıcı, sindirim, sinir, boşaltım, kan ve dolaşım sistemi rahatsızlıkları, soğuk algınlığı ve üst solunum yolu enfeksiyonları, alerjik nezleler gibi solunum sistemi rahatsızlıkları, baş ve diş ağrısı, yara veya yanıklarda haricen, gut, romatizma, raşitizm ve kas gevşetici olarak kullanılmaktadır (İlisulu, 1992; Mohsin ve ark., 1989; Kökçü, 2015).

Bunun dışında baharat olarak yemeklerde kullanılmakta, çay veya gıda bozulmasını önleyici olarak gıda sektöründe de kullanılmaktadır (Ayar ve ark., 2002). Thymus'un gövde ve yapraklarından sarı, kahverengi ve yeşil-gri renklerde doğal boya elde edilerek boya bitkisi olarak kullanılmaktadır (Anonim, 1991; Arslan ve Kızıl, 2001). Zirai açıdan da kullanılan ve kimyasal kullanmadan organik tarıma katkı sağlayan, Thymus gibi bitki türlerinin toprak üstü organlarından terleme suretiyle buharlaşarak etrafa yaydıkları kimyasallar bazı zararlı bitkilerin gelişmesi üzerine olumsuz etkilerde bulunduğu belirtilmiştir (Karaltın ve ark., 2001). Bunların dışında arıcılıkta da kullanıldığı ve anzer balı yapımında da etkili olduğu bilinmektedir.

Etnobotanik açıdan büyük bir önem taşıyan Thymus zygioides türünün, bilinçsiz kullanımlarının neden olduğu olumsuz sonuçlar ortaya çıkmaktadır. Özellikle etnobotanik açısından her anlamda değerlendirilmeye çalışılan bu türün endemik olan varyetesi tehlikeye girmekte hatta adım adım yok olmaya sürüklemektedir. Türün bilinçsiz tüketimleri kontrol altına alınarak, endemik varyetesi koruma altına alınırken, kozmopolit olan varyetesi kültüre 
alınarak etnobotanik kullanım amaçlarından özellikle drog elde etmede kullanılabilir. Araştırmamızda yapılan toprak analizleri sayesinde kültüre alınırken gerekli olan edafik koşullar kolaylıkla sağlanabilir.

\section{Kaynaklar}

Alan, S. ve Koca, F., 2007. Eskişehir'de Yetişen Thymus L. (Labiatae) Türleri Üzerinde Anatomik Araştırmalar, Anadolu Üniversitesi Bilim ve Teknoloji Dergisi, Cilt:8, Say1:1, s.161-180.

Altundağ, Ş. ve Aslım B., 2005. Kekiğin Bazı Bitki Patojeni Bakteriler Üzerine Antimikrobiyal Etkisi. Orlab On-Line Mikrobiyoloji Dergisi, Cilt:3, Say1:7, s.12-14.

Anonim. 1991. Bitkilerden Elde Edilen Boyalarla Yün Liflerinin Boyanması. T.C. Sanayi ve Ticaret Bakanlığı, Küçük Sanatlar Sanayi Bölgeleri ve Siteleri Genel Müdürlüğü, 167 s., Ankara.

Arslan, N. ve Kızıl, S. 2001. Boya Bitkileri. TİGEM, 79,48-51.

Ayar, A., Özcan, M., Akgül, A., 2002. Tereyağının mikrobiyolojik kalitesi üzerine kekik ve adaçayı ekstraktlarının etkisi. Ondokuz Mayıs Üniversitesi, Ziraat Fakültesi Dergisi, Cilt: 17, Sayı:2, s.45-49.

Bizimbitkiler.org, 2016. Bizimbitkiler, http://www.bizimbitkiler.org.tr/v2/turkce.php

Davis P.H., 1982. Flora of Turkey and East Egean Islands, Vol. 7. Edinburgh Uni. Press, UK.

Heywood ve ark., 1964,1980. Flora Europaea Vol. 1-5. Cambridge Univ. Press, Cambridge.

İlisulu, K. 1992. İlaç ve Baharat Bitkileri. Ankara Üniversitesi, Ziraat Fakültesi Yayınları, Yayın No: 1256/360, 302 s., Ankara.

Karaltın, S., Kıllı, F. ve Uslu, Ö.S. 2001. Allelopati ve Ekolojik Sistemde Bitkiler Aras1 Rekabet Üzerine Etkisi. Türkiye 2. Ekolojik Tarım Sempozyumu, 14-16 Kasım, Antalya Narenciye ve Seracılık Araş. Enst. Müdürlüğü, ETO, 218-232 s., Antalya.

Kesercioğlu, T., Tung, T., Nakipoğlu, M., 1990. Batı Anadolu'nun Endemik Türleri Üzerine Araştırmalar. Tymus zygioides Grieb. var. Lycaonicus (Celak) Ronniger. (Yer Kekiği) Üzerinde Morfolojik, Anatomik ve Sitolojik Araştırmalar. Ormancılık Araştırma Enstitüsü Yayınları 71:75-90. 
Kökçü, B., 2015. Lapseki (A1/A), Çanakkale, Türkiye) ve Çevresinin Etnobotaniği (Yüksek Lisans Tezi). Çanakkale Onsekiz Mart Üniversitesi, Fen Bilimleri Enstitüsü Biyoloji Anabilim Dalı, Çanakkale.

Metcalfe, C. R., Chalk, L., 1950. Anatomy of The Dicotyledons 2, Oxford University Press, London.

Mohsin, A., Shoh, A.H., Al-Yahya, M.A., Tarıq, M., Tanıra, M.O.M. ve Agel, A.M. 1989. Analgesic, Antipyretic Activity and Phytochemical Screening of Some Plants Used in Traditional Arab System of Medicine. Fitoterapia. 2:174-177.

Öztürk, M., Gökçeoğlu, M., Pirdal, M., 1983. Bitki-Toprak İlişkileri Uygulama Klavuzu. Ege Üniversitesi, Fen Fakültesi, Biyoloji Bölümü, İzmir.

TPL, 2013. The Plant List, http://www.theplantlist.org/

Uysal, İ., Öztürk, M., Pirdal, M., 1991. Sideritis trojana Bornm, Endemik Türünün Morfolojisi, Anatomisi ve Ekolojisi. Doga Turk. bot. Derg, 15: 371-9.

Yentür, S., Öz, G. C., 2013. Bitki Anatomisi. İstanbul Üniversitesi Fen Fakültesi Biyoloji Bölümü, Say1:5149, No:231, s.335. 